\title{
Use of home visits increases data completion and retention in studies involving family members
}

\author{
Katie Biggs*, Cindy Cooper \\ From 3rd International Clinical Trials Methodology Conference \\ Glasgow, UK. 16-17 November 2015
}

\section{Background}

Previous research indicates that health and well-being is adversely affected in family members of a child with a health condition but the practical aspects of recruiting, retaining and collecting data from family members are not well reported.

Using data from a cross-sectional observational study, we looked at whether use of home visits had an effect on the data completion and retention of family members.

\section{Methods}

Various recruitment and data collection methods were used in the study including an option to conduct home visits with the families.

549 families living with a child with ADHD, and 123 families without any children with ADHD (control) were recruited.

\section{Results}

When a home visit was conducted $84 \%$ of questionnaires were completed, compared to $59 \%$ when no home visit was conducted $(\mathrm{X} 2=51.194, \mathrm{df}=1, \mathrm{p}<0.00)$.

A binomial logistic regression model included home visit, presence of ADHD and employment as significant variables, though the effect of employment was negligible.

In regards to data completion, a home visit increased the likelihood of completing the primary outcome. When a home visit was conducted $96 \%$ of children completed the CHU-9, compared to $90 \%$ without a visit $(\mathrm{X} 2=12.300, \mathrm{df}=1, \mathrm{p}<0.00)$ and $85 \%$ of adults completed the EQ5D with a home visit, compared to $69 \%$ without $(\mathrm{X} 2=37.038, \mathrm{df}=1, \mathrm{p}<0.00)$.

University of Sheffield, Sheffield, UK

(c) 2015 Biggs and Cooper This is an Open Access article distributed under the terms of the Creative Commons Attribution License (http://creativecommons.org/licenses/by/4.0), which permits unrestricted use, distribution, and reproduction in any medium, provided the original work is properly cited. The Creative Commons Public Domain Dedication waiver (http://creativecommons.org/ publicdomain/zero/1.0/) applies to the data made available in this article, unless otherwise stated.

\section{Discussion}

Retention and data completion was better in families that received a home visit, particularly in families where there was a child with ADHD.

Published: 16 November 2015

doi:10.1186/1745-6215-16-S2-O24

Cite this article as: Biggs and Cooper: Use of home visits increases data completion and retention in studies involving family members. Trials 2015 16(Suppl 2):O24.

Submit your next manuscript to BioMed Central and take full advantage of:

- Convenient online submission

- Thorough peer review

- No space constraints or color figure charges

- Immediate publication on acceptance

- Inclusion in PubMed, CAS, Scopus and Google Scholar

- Research which is freely available for redistribution 